\title{
EFFECT OF CROTON URUCURANA BAILL. EXTRACTS AGAINST ATTA SEXDENS RUBROPILOSA FOREL (HYMENOPTERA: FORMICIDAE)
}

\author{
MILENA TIMICH \& DÉBORAH YARA A. C. DOS SANTOS
}

\author{
Departamento de Botânica, Instituto de Biociências, Universidade de São Paulo, \\ Rua do Matão, 277, 05508-090 - São Paulo, SP, Brazil. \\ * Corresponding author: e-mail: dyacsan@ib.usp.br.
}

\begin{abstract}
Effect of Croton urucurana Baill. extracts against Atta sexdens rubropilosa Forel (Hymenoptera: Formicidae)) Leaf-cutting ants of the Atta genus cause serious problems in Brazilian agriculture. Currently, research efforts are directed to find specific compounds to fight these ants, their symbiont fungus, or both. This study investigates whether direct topical application of hexanic, dichloromethanic, and methanolic leaf extracts of Croton urucurana affects mortality rate of Atta sexdens rubropilosa workers. In spite of previous research describing insecticide property related to this Croton species, no significant difference was observed between mortality rates of ants treated with extracts and control. Although the Croton extracts were not toxic for ants, further bioassays with the symbiotic fungus should be conducted.
\end{abstract}

Keywords: Croton urucurana, Euphorbiaceae, Atta sexdens rubropilosa, leaf-cutting ants, bioassay, $\beta$ sitosterol.

RESUMO - (Efeito de extratos de Croton urucurana Baill. sobre Atta sexdens rubropilosa Forel (Hymenoptera: Formicidae)) As formigas cortadeiras do gênero Atta causam sérios problemas à agricultura brasileira. Atualmente, buscam-se substâncias que sejam específicas a essas formigas, ao seu fungo simbionte ou a ambos. O objetivo deste trabalho foi verificar se a aplicação tópica direta de extratos hexânico, diclorometânico e metanólico de folhas de Croton urucurana influenciam a taxa de mortalidade das operárias. Apesar de dados anteriores demonstrarem o efeito inseticida dessa espécie de Croton, não foi verificada diferença significativa na taxa de mortalidade das formigas tratadas com os extratos e o controle. No entanto, novos bioensaios usando o fungo simbionte devem ser realizados.

Palavras-chave: Croton urucurana, Euphorbiaceae, Atta sexdens rubropilosa, formigas-cortadeiras, bioensaio, $\beta$-sitosterol.

\section{Introdução}

Leaf-cutting ants of the Atta genus, Attini tribe, Myrmicinae family, occur restrictedly in the Americas, distributed from central Argentina to southern USA (Herrera \& Pellmyr 2002). These social insects live in nests built as a succession of chambers that are used to grow the symbiont fungus or to dispose of waste. These ants cause considerable damage to agriculture in Brazil (Fernandes et al. 2002) and together with ants of the Acromyrmex genus stand out as the main insect pest in tropical and subtropical regions in the American continent. It is estimated that between $12 \%-17 \%$ of the total production of leaves in tropical forests is consumed by ants of the Atta genus, with a significantly higher impact on these environments, compared to any other herbivore (Herrera \& Pellmyr 2002).

Currently, control strategies against this pest are based on unspecific manufactured insecticides that are harmful to non-target insects and contaminate the environment (Fernandes et al. 2002, Santos-Oliveira 2006). These side effects have prompted the search for insecticides with specific action against leaf-cutting ants, their symbiont fungus, or both (Fernandes et al. 2002).

Plants like Spiranthera odoratissima A.St. Hil (Terezan et al. 2010), Azadirachta indica A. Juss.
(Oliveira et al. 2006) and Citrus reticulata Blanco (Fernandes et al. 2002) have been associated with proven toxic effect against Atta sexdens rubropilosa Forel.

Croton is a Euphorbiaceae genus that includes approximately 1,300 species distributed in tropical and subtropical regions of the New and the Old World (Govaerts et al. 2000). Plants of this genus have high levels of biologically active components, such as diterpenoids and alkaloids. Additionally, it comprises several aromatic species due to the presence of volatile oils (Salatino et al. 2007).

Croton urucurana Baill., also known as dragon blood, occurs in a wide area of the Brazilian territory, from the state of Bahia to Rio Grande do Sul and Mato Grosso (Salatino et al. 2007). Its popular name derives from the fact that the trunk releases red latex that is used as analgesic in folk medicine (Peres et al. 1997). Moreover, Silva et al. (2009) demonstrated that semipurified fractions of $C$. urucurana bark extracts significantly increased the mortality of Anagasta kuehniella Zeller (Lepidoptera: Pyralidae), suggesting the potential use as natural insecticide.

In this sense, the present study evaluated the effect of hexanic, dichloromethanic, and methanolic extracts of $C$. urucurana leaf extracts on the mortality of Atta sexdens rubropilosa workers using a direct contact bioassay. 


\section{Material and methods}

Preparation of extracts - Ten grams of dry and finely powdered leaves of $C$. urucurana were submitted to $8 \mathrm{~h}$ serial extraction in a Soxhlet apparatus using hexane, dichloromethane, and methanol. Extracts were concentrated separately to dryness under reduced pressure in a rotatory evaporator and then diluted in the respective solvents to $0.5 \%, 1 \%$, and $2 \%$ solutions.

Bioassays - The ant nests used are kept in the Laboratory of Phytochemistry, Department of Botany, Institute of Biosciences, University of São Paulo, into controlled room at $24 \pm 1^{\circ} \mathrm{C}$ and $70 \%-80 \%$ relative humidity. Ants are given a daily supply of leaves of Acalypha wilkesiana Mull.Arg. and corn grits.

Five nests (replicates) were used during three bioassays, each one with five treatments: dry control (C1), solvent control (C2), $0.5 \%$ extract (T1), $1 \%$ extract (T2) and $2 \%$ extract (T3). For each replicate, 50 worker-ants (10 for each treatment) with cephalic capsule measuring between $2.0-2.5 \mathrm{~mm}$ were randomly collected and placed in a Petri dish with water and an artificial solid diet prepared with $0.1 \%$ yeast extract and $1.5 \%$ agar in $100 \mathrm{~mL}$ distilled water offered in a small plastic lid. The diet was replaced every $24 \mathrm{~h}$ to prevent contamination with microorganisms (Bueno et al. 1997).

Each ant was immobilized using tweezers. Then, $1 \mu \mathrm{L}$ of each extract at one of the concentrations used was dropped on the ant using a pipette (Fernandes et al. 2002). For the solvent control group, $1 \mu \mathrm{L}$ of pure solvent was used. Petri dishes were kept under the same conditions used for nests. The number of dead ants after exposure to treatments was recorded daily, for 25 days (Bueno et al. 1997).

Analysis of results - Survival rate of ants in each treatment was analyzed based on the day when $50 \%$ of ants were alive $\left(S_{50}\right)$ (Alonso \& Santos 2013). The data obtained with the five repeats of each treatment were analyzed using ANOVA to detect statistical differences. When these differences were observed, the a posteriori Tukey test was used to detect which treatment produced different results.

Analysis of secondary metabolites - The hexanic extract was submitted to gas chromatography-mass spectrometry (GC-MS) to identify the organic compounds in it. A HP-5MS column was used with injector temperature set at $250^{\circ} \mathrm{C}$ and the following heating gradient: $4 \mathrm{~min}$ at $150^{\circ} \mathrm{C}$, a $150^{\circ} \mathrm{C}$ increase to $320^{\circ} \mathrm{C}$ at $6^{\circ} \mathrm{C} / \mathrm{min}$, and $2 \mathrm{~min}$ at $320^{\circ} \mathrm{C}$. The substances were identified comparing mass and relative intensity of peaks with data available in the MassBank.jp online databank (http://massbank.jp).

\section{Results and Discussion}

Comparing both dry (C1) and solvent (C2) controls, no statistically significant differences were observed with all three solvents used (Table 1). The absence of considerable deleterious effects by applying solvents topically onto leaf-cutting ants has already been reported in other studies. Similar findings were observed by Fernandes et al. (2002) in a study that evaluated the effect of the oil of citric fruit seeds diluted in hexane and ethyl acetate, and by Alonso \& Santos (2013), in an investigation of the efficiency of hexanic extracts from seeds of two Euphrorbiaceae species.

Here, as a rule, the leaf extracts of $C$. urucurana did not exhibit insecticide effect against Atta sexdens rubropilosa worker ants (Table 1 ). The $S_{50}$ values observed for all treatments did not differ from dry or solvent controls. At dry control, the $S_{50}$ values ranged from 7.5 to 10 days depending on the bioassay. Bueno et al. (1997) have already found $S_{50}$ of 10 days in a similar assay. Despite the absence of statistical difference, a slight decrease at $S_{50}$ values was noted with higher doses of hexanic and dichloromethanic extracts, but not for the methanolic extract (Table1).

Table 1. Mean day when $50 \%\left(\mathrm{~S}_{50}\right)$ of leaf-cutting ants survived, with different bioassays. C1: dry control; C2: control with solvent; T1: extract $0.5 \%$; T2: extract $1 \%$; T3: extract $2 \%$. Identical letters in the same column indicate the absence of significant differences. $S_{50}$ hexane $=p>0.4307, S_{50}$ dichloromethane $=$ $p>0.5663, S_{50}$ methanol $=p>0.8893$.

\begin{tabular}{llll}
\hline Treatment & $S_{50}$ hexane & $S_{50}$ dichloromethane & $S_{50}$ methanol \\
\hline C1 & $10 \pm 1.936 \mathrm{a}$ & $7.5 \pm 1.095 \mathrm{~b}$ & $8+2.987 \mathrm{c}$ \\
$\mathrm{C} 2$ & $8 \pm 1.850 \mathrm{a}$ & $9 \pm 2.274 \mathrm{~b}$ & $10+35.579 \mathrm{c}$ \\
$\mathrm{T} 1$ & $8.5 \pm 2.244 \mathrm{a}$ & $9 \pm 3.489 \mathrm{~b}$ & $10+3.475 \mathrm{c}$ \\
$\mathrm{T} 2$ & $7.5 \pm 2.387 \mathrm{a}$ & $8.5 \pm 3.817 \mathrm{~b}$ & $11+2.151 \mathrm{c}$ \\
$\mathrm{T} 3$ & $6.5 \pm 3.061 \mathrm{a}$ & $7.5 \pm 2.043 \mathrm{~b}$ & $9+3.347 \mathrm{c}$ \\
\hline
\end{tabular}


In spite of the higher mortality in Anagasta kuehniella larvae observed by Silva et al. (2009) with the exposure to $C$. urucurana extracts, the insecticidal action of this plant could not be confirmed in Atta sexdens rubropilosa.

Although no statistical significance was observed among the $S_{50}$ for all biossays, the data obtained for the exposure to hexanic extracts in the present study pointed out an interesting pattern of survival. Looking through survival curves, there is a visual distinction of dry-control ants (C1) comparing to the others (C2, T1, T2, T3) (Fig. 1). The number of survivors was always higher from day 1 until day 21 . Comparing the survival on a daily basis, a significant difference was observed in $S_{50}$ of ants from the dry control and the other treatments between days 3 and 6 (day $3 \mathrm{P}>0.0504$; day $4 \mathrm{P}>0.027$; day $5 \mathrm{P}>0.0142$ and day $6 \mathrm{P}>0.0327$ ), reinforcing that visual difference. For dichloromethanic and methanol extracts no distinction were found throughout the bioassays.

Dutra et al. (2011) reported on the cytotoxic activity of hexanic and dichloromethanic extracts of $C$. urucurana against Artemia salina. Moreover, these extracts also exhibited in vitro antibacterial action (Oliveira et al. 2008). The presence of $\beta$-sitosterol-Oglycoside and of other substances in the methanolic, hexanic, and hydroalcoholic extracts of $C$. urucurana bark was pointed out to be behind the bactericidal action against Staphylococcus aureus (Peres et al. 1997). Among other minor compounds, the GC-MS revealed $\beta$-sitosterol as an important constituent of hexanic extracts of $C$. urucurana.

Finally, before abandoning the use of extracts of Croton urucurana as an alternative control of leafcutting ants, further bioassays investigating the toxic effect of these extracts could be performed. Miyashira et al. (2012) using distinct doses of caffeine detected high toxic effect of this compound against the symbiotic fungus but none effect against the insect. Since there is a strict dependency between this insect and the symbiotic fungus, the use of a fungicide incorporated into baits could be an interesting alternative to actual unspecific insecticides.

\section{Acknowledgments}

The authors thank FAPESP (Fundação de Amparo à Pesquisa do Estado de São Paulo) for financial support, and MT fellowships (2011/20019-2 and 2012/06845-0). DYACS is fellow researcher of CNPq (Conselho Nacional do Desenvolvimento Científico e Tecnológico, Brazil). 


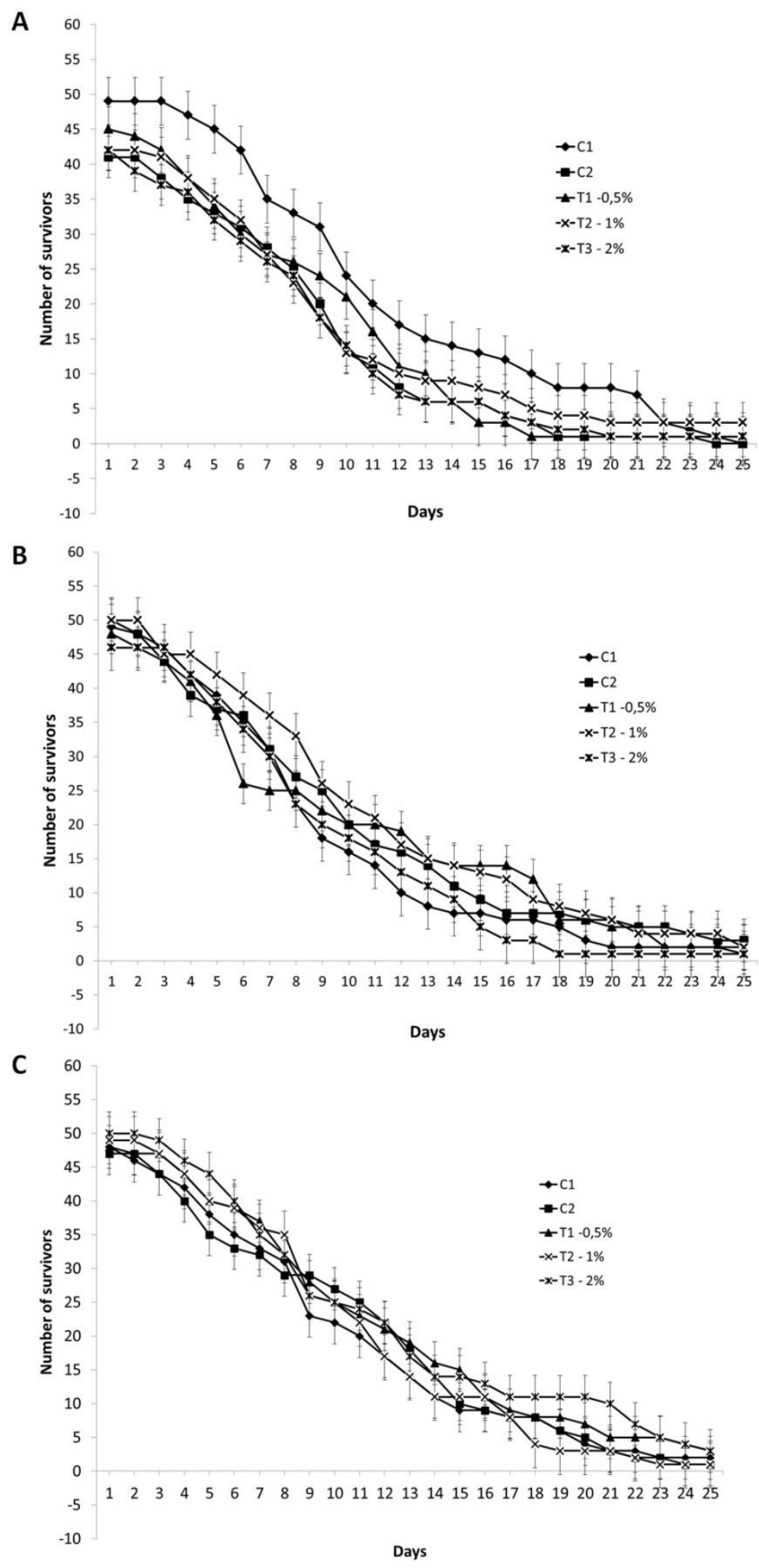

Fig. 1 - Survival curve of Atta sexdens rubropilosa workers submitted to the bioassays of topical toxicity with extracts of Croton urucurana leaves. A. Assay with hexanic extract. B. Assay with dichloromethanic extract. C. Assay with methanolic extract. 


\section{References}

ALONSO, E.C. \& SANTOS, D.Y.A.C. 2013. Ricinus communis ans Jatropha curcas (Euphorbiaceae) seed oil toxicity against Atta sexdens rubropilosa (Hymenoptera: Formicidae). J. Econ. Entomol. 106: 742-746.

BUENO, O.C., MARIA, S.C., MORINI, M.S.C., PAGNOCCA, F.C., HEBLING, M.J.A., SILVA, O.A. 1997. Sobrevivência de operárias de Atta sexdens rubropilosa Forel (Hymenoptera: Formicidae) isoladas do formigueiro e alimentadas com dietas artificiais. An. Soc. Entomol. Bras. 26: 107-113.

DUTRA, L.M., ALVES, K.S., RAMOS, L.M., COSTA, M.B. 2011. Fitoquímica de Croton urucurana Baillon (Euphorbiaceae): identificação, isolamento e avaliação citotóxica de metabólitos secundários. In Anais do IX Seminário de Iniciação Científica, VI Jornada de Pesquisa e Pós-Graduação e Semana Nacional de Ciência e Tecnologia. Universidade Estadual de Goiás. Goiânia, p. 1-4.

FERNANDES, J.B., DAVID, V., FACCHINI, P.H., SILVA, M.F.G.F., FILHO, E.R., VIEIRA, P.C. 2002. Extrações de óleos de sementes de citros e suas atividades sobre a formiga cortadeira Atta sexdens e seu fungo simbionte. Quim. Nova 25: 1091-1095.

GOVAERTS, R., FRODIN, D.G., RADCLIFFE-SMITH, A. 2000. World checklist and bibliography of Euphorbiaceae (and Pandaceae). Royal Botanic Gardens. Kew.

HERRERA, C.M. \& PELLMYR, O. 2002. Plant-Animal interactions: an evolutionary approach. Blackwell Publishing. Oxford.

MYASHIRA, C.H., TANIGUSHI, D.G., GUGLIOTTA, A., SANTOS, D.Y.A.C. 2012. Influence of caffeine on the survival of leaf-cutting ants Atta sexdens rubropilosa and in vitro growth of their mutualistic fungus. Pest Manag. Sci. 68: 935-940.
OLIVEIRA, I.S., LIMA, J.C.S., SILVA, R.M., MARTINS, D.T.O. 2008. Triagem da atividade antibacteriana in vitro do látex e extratos de Croton urucurana Baillon. Rev. bras. farmacogn. 18: 587-593.

OLIVEIRA, M.F.S.S., BUENO, O.C., MARINI, T., REISS, I.C., BUENO, F.C. 2006. Toxicity of Azadirachta indica to leaf-cutting ant Atta sexdens rubropilosa (Hymenoptera: Formicidae). Sociobiology 47: 423-431.

PERES, M.T.L.P., DELLE MONACHE, F., CRUZ, A.B., PIZZOLATTI, M.G., YUNES, R.A. 1997. Chemical composition ant antimicrobial activity of Croton urucurana Baillon (Euphorbiaceae). J. Ethnopharmacol. 56: 223-226.

SALATINO, A., SALATINO, M.L.F., NEGRI, G. 2007. Traditional uses, chemistry and pharmacology of Croton species (Euphorbiaceae). J. Braz. Chem. Soc. 18: 11-33.

SANTOS-OLIVEIRA, M.F.S., BUENO, O.C., MARINI, T., REISS, I.C., BUENO, F.C. 2006. Toxicity of Azadirachta indica to leaf-cutting ant Atta sexdens rubropilosa (Hymenoptera: Formicidae). Sociobiology 47: 421-431.

SILVA, L.B., SILVA, W., MACEDO, M.L.R., PERES, M.T.P. 2009. Effects of Croton urucurana extracts and crude resin on Anagasta kuehniella (Lepidoptera: Pyralidae). Braz. Arch. Biol. Techn. 52: 653-664.

TEREZAN, A.P., ROSSI, R.A., ALMEIDA, R.N.A., FREITAS, T.G., FERNANDES, J.B., SILVA, M.F.G.F., VIEIRA, P.C., BUENO, O.C., PAGNOCCA, F.C., PIRANI, J.R. 2010. Activities of extracts and compounds from Spiranthera odoratissima St. Hil. (Rutaceae) in leaf-cutting ants and their symbiotic fungus. J. Braz. Chem. Soc. 21 : 882-886. 